\title{
FORECASTING NEW PRODUCT SALES
}

\author{
R. Siriram ${ }^{1 *}$ and D.R. Snaddon ${ }^{2}$ \\ Department of Mechanical, Industrial and Aeronautical Engineering \\ University of Witwatersrand, South Africa \\ ${ }^{1}$ raj.siriram@mea.dimensiondata.com, ${ }^{2}$ roy.snaddon@wits.ac.za
}

\begin{abstract}
This paper tests the accuracy of using Linear regression, Logistics regression, and Bass curves in selected new product rollouts, based on sales data. The selected new products come from the electronics and electrical engineering and information and communications technology industries. The eight selected products are: electronic switchgear, electric motors, supervisory control and data acquisition systems, programmable logic controllers, cell phones, wireless modules, routers, and antennas. We compare the Linear regression, Logistics regression and Bass curves with respect to forecasting using analysis of variance. The accuracy of these three curves is studied and conclusions are drawn. We use an expert panel to compare the different curves and provide lessons for managers to improve forecasting new product sales. In addition, comparison between the two industries is drawn, and areas for further research are indicated.
\end{abstract}

\section{OPSOMMING}

Hierdie artikel toets die akkuraatheid van die gebruik van linêere regressie, logistiese regressie en Bass-krommes by die bekendstelling van nuwe produkte gebaseer op verkoopsdata. Die geselekteerde nuwe produkte is uit die elektriese en elektroniese asook informasietegnologie- en kommunikasie bedrywe. Linêere regressie, logistiese regressie en Bass-krommes word vergelyk ten opsigte van vooruitskatting deur variansie te ontleed. Die akkuraatheid word ontleed en gevolgtrekkings gemaak. Die doel is om vooruitskatting van nuwe produkverkope te verbeter.

\footnotetext{
* Corresponding author
} 


\section{INTRODUCTION}

Managers face rapid technological change. They face smaller windows of opportunity, quicker time-to-market, lower inventories, higher returns on investment, etc. Managers try to outperform their competitors, asking when the firm should launch newer and phase out older products. Which stocking policies and distribution strategies should they adopt? Managers often have to answer such questions, knowing that buyers (customers) and sellers (suppliers) in the supply chain face similar decisions. Rapid technological change and supply chains force managers to innovate dynamically. [14] see dynamic innovation as "the process of technological innovation over time, or more specifically, the process of creating a series of innovations over time". On dynamic innovation [1], [2], [16], this paper considers one aspect, namely the change of sales over time for a specific product. The periods and products selected for study are characterised by rapid technological change ("era of ferment" [14]) found in technology life cycles. Here the sustainability of the technology is questioned. In addition Logistics regression is used as a product-life cycle tool to forecast industry sales.

We measure parameters by collecting and analysing new product sales data. We use Logistics regression as the basis for analysis. Logistics regression is compared with Linear regression and Bass curves. Well-known statistical techniques are used to test accuracy. The mathematical curves are evaluated through an expert panel, and suggestions for improvement are provided.

\section{RESEARCH OBJECTIVES}

The objectives of this research are to:

- $\quad$ provide some background on Logistics regression theory, especially for new product sales;

- compare Logistics regression to other forecasting models, namely Linear regression and the bass curve;

- $\quad$ compare the Logistics regression, Linear regression and Bass curves using analysis of variance (ANOVA) for the products selected;

- $\quad$ use an expert panel to validate the results; and

- $\quad$ suggest areas for further research.

\section{LITERATURE SURVEY}

The background covers the product life-cycle, Linear regression, Logistics regression and Bass curves for predicting the initial part of the product life-cycle. [18] and [5] comment upon such ' $\mathrm{s}$-Curve' technology life cycle models. Forecasting is then discussed (especially with respect to technologies).

First we clarify terms: 'product' when used in product life-cycle; and 'product' as in new product sales and technology. When used in the product-life cycle, the general product is being considered with all suppliers. If the product is 'electronic chips', for example, then all electronic chips are referred to, whether made by Intel, Motorola, AMD, etc. If, however, the product refers to 'new product sales', then it refers to the sales of one particular supplier, e.g. Motorola. 'Technology' refers to underlying principles from which products start, whether in single or multiple firms. An example will illustrate these terms. Savery, Newcomen, and Watt saw steam provide a source of power. Using steam technology they produced steam engines (a product). Building and selling steam engines formed new product sales for the firm Boulton and Watt. When added to other steam engine builders e.g., Robey and Sons; Maudslay, Sons, and Field; R.Hornsby and Sons, etc. - the total supply of steam engines can be logged over time by the product-life cycle. The product-life cycle initially increased with applications in locomotives and steam boats, but decreased as diesel-electric and turbines replaced them. 


\subsection{The product-life cycle and diffusion models}

Product-life cycles show the total volume of a product or service transcended over time. The product-life cycle shows an introductory phase, then growing, reaching maturity, and declining. In the introductory phase, the product or service is relatively unknown in the market, and sales are initially low. An increase in volume of the product or service in the market can be achieved in many ways: some of these include higher quality, differentiation of the product through niche markets, pricing strategies, better service levels, etc. While these strategies influence the product-life cycle, we take Logistics regression to form the basis (benchmark).

Maturity and decline in the product-life cycle may occur when old technologies are replaced by newer technologies (for example, sail [wind] giving way to steam in the $19^{\text {th }}$ century). So this may in turn be a reversed S-Curve of technologies. [9] argue that the force driving a generation of S-Curves is the diffusion of information. They say that the use of diffusion models is encouraging. However, further empirical work is necessary, employing a diffusion modelling framework to test hypotheses related to life cycle dynamics. Typical questions raised include: How does the number of suppliers change over the life cycle of the product? How does the number of brands available in a market influence the growth of the product? How does rivalry among competitors in an industry affect the life cycle of the product?

Attempts to select appropriate growth models include these:

- [11] review and compare saturation models and Logistics growth (with emphasis on the underlying probability models).

- [22] deal with the selection and estimation of either the Logistics or Gompertz curve (for technological forecasting).

- [21] later covers the selection of the following (technological) growth curves: Logistic, Gompertz, Mansfeld-Blackman, Linear Gompertz, Weibull, Bass, Nonsymmetric responding logistic model (NSRL), Harvey, and Extended Riccati.

- [22] provided a multiple of indicators and multiple causes (MIMC) to evaluate forecasting effectiveness, taking accuracy, bias, timeliness, and cost into account.

While findings vary, the message is that a deeper understanding of models and their associated parameters is required. The growth process is complex, subject to many supply and demand influences.

\section{MATHEMATICAL ANALYSIS}

We consider three methods: the Linear regression, Logistics regression, and Bass curves. From [20]'s work the question is which to consider, for the work here. As a reference Logistics regression can be measured against Linear regression and the Bass curve.

\subsection{The Linear Regression and Logistics Regression}

From [21]'s work, the question is, which to consider for the work here? Criteria include the accuracy of fitting historical data, and we agree with Martino [10], who pointed out that a Logistics regression should best fit the underlying dynamics of the process, produce historical data, and are able to predict future behaviour. Table 1 shows the basis of the Linear regression and Logistics regression. To discuss the historical data and future behaviour, consider the slope of these curves. From Table 1, the logistic regression is represented by the function $Y=m b^{t}$ where $Y$ is the sales, $t$ is the time from the start, $b$ the slope, and $\mathrm{m}$ the constant.

\begin{tabular}{|l|l|l|l|l|}
\hline Curve & Equation & At the start; $\mathrm{t}=\mathbf{0}$ & Slope & Constants \\
\hline Linear regression & $\mathrm{Y}=\mathrm{at}+\mathrm{b}$ & $\mathrm{Y}=\mathrm{b}$ & $\mathrm{Y} / \mathrm{a}$ & $\mathrm{a}, \mathrm{b}$ \\
\hline Logistics regression & $\mathrm{Y}=\mathrm{mb}^{\ddagger}$ & $\mathrm{Y}=\mathrm{mb}$ & $\mathrm{b}$ & $\mathrm{m}$ \\
\hline
\end{tabular}

Table 1: Comparison of the Linear regression and Logistics regression 
The Bass curve is discussed next.

\subsection{Bass curve}

For the bass curve, the general bass curve is fitted by the following equation:

$\mathrm{S}(\mathrm{t})=\mathrm{pm}+(\mathrm{q}-\mathrm{p})^{*} \mathrm{~S}(\mathrm{t}-1)-(\mathrm{q} / \mathrm{m})^{*} \mathrm{~S}(\mathrm{t}-1)^{\wedge} 2$

Where:

- $\quad \mathrm{S}(\mathrm{t})$ is the number of new adopters during time $\mathrm{t}$;

- $\mathrm{S}(\mathrm{t}-1)$ is the cumulative number of adopters for the new product through the previous time period $(\mathrm{t}-1)$;

- $\quad \mathrm{p}$ is the coefficient of innovation;

- $\quad \mathrm{q}$ is the coefficient of imitation;

- $\quad \mathrm{m}$ is the size of the market

In order to solve the above coefficients, the equation is transformed into a second order Linear equation of this form:

$S(t)=a+b * S(t-1)-c^{*} S(t-1)^{\wedge} 2$

Where:

- $\quad a=p^{*} m$

- $\quad b=(q-p)$

- $\quad c=-q / m$

- $\quad m=\left[-b \pm J\left(b^{2}-4 a c\right)\right] / 2 a$

The coefficients a, b, c are solved by Linear regression based on the available data.

Having discussed the Linear regression, Logistics regression, and Bass curves, the research methodology is discussed next.

\section{RESEARCH METHODOLOGY}

The research consisted of four parts:

- The first part looks at accuracy of curves, fits on new product sales data for the Linear regression, Logistics regression, and the bass curves.

- $\quad$ The second part compares the curves found, using known statistical techniques.

- $\quad$ The third part evaluates the results through an expert panel; and

- $\quad$ The fourth part suggests measures for improving the mathematical forecasts.

The research consisted of data analysis from specific firms. The selection was based on accessibility to data. For the selected firms, contact persons in the firms were identified telephonically. After assessing the firms' interest in the research, a document giving an overview of the research together with a data input table was e-mailed. The persons contacted ranged from managing directors to financial directors, sales and marketing managers, and business development managers. In some cases the researchers entered into detailed discussions with firms. This was necessary as the firms are interested in the results. No claim is made that the data used is random. For the expert panel participants were selected from the selected firms, and they were deemed to be experts in the technologies studied. The expert panel consisted of general managers, products managers, and marketing managers. The electronics and electrical engineering industry expert panel had seven members, and the panel for the ICT industry had eight members. 


\subsection{Industry selection and data analysis}

Two industry sectors were selected: the electronics and electrical, and information and communications technology industries (ICT). These industries were selected because:

- $\quad$ they represented the researchers' areas of interest;

- $\quad$ these industries regularly develop new products; and

- $\quad$ comparisons can be made between products within the industry sectors, provided

- $\quad$ that adequate data is available.

\subsection{Data analysis}

The results were analysed using Linear regression, Logistics regression, and Bass curves. Microsoft Excel was used for the analysis. The R-square goodness of fit test was used to test data fit, and the different methods were compared by comparing the mean absolute percentage error (MAPE).

\section{RESEARCH RESULTS}

\subsection{Analysis of results}

All data was accumulated on a monthly basis. For the purposes of normalisation, the length of time, or number of periods to be forecasted, must be calculated (known as the forecasting horizon). Generally, data is extrapolated for half the number of past data collected: (t/2) if even, (t-1)/2 if odd.

The industry sectors and product analysis are discussed next.

\subsection{Industry sectors and product analysis}

The mean absolute percentage error (MAPE) and the R-squared for the Linear regression, Logistics regression, and Bass curves are shown in Table 2. The model showing the lowest MAPE is also indicated. In all eight cases the Logistics regression has a lower MAPE than the Linear regression or the Bass curve. This indicates that the Logistics regression is a better option for the data than the Linear regression or the Bass curve. Table 3 shows the results (constants/parameters) and ANOVA for each product respectively (long range forecasts). The ANOVA shows in all eight cases that the results are not significant - i.e. there are no significant differences between the curves. We test the null hypothesis $H_{0}: \mu_{1}=\mu_{2}=\mu_{3}$ and the alternative hypothesis $H_{1}: \mu_{1} \neq \mu_{2} \neq \mu_{3}$. We define $\mu_{1}=\mu_{2}=\mu_{3}$ as the variances for the Linear regression, Logistics regression, and Bass curves respectively for the electronics and electrical engineering industry; and $\mu_{1}=\mu_{\underline{2}}=\mu_{\underline{3}}$ are the variances for the Linear regression, Logistics regression, and Bass curves respectively for the ICT industry. First the F-ratio of variances is calculated, and then compared with F-Table values; thereafter the significance level is established. We test for equal variances between Linear regression, Logistics regression, and the Bass curves. In all eight cases we have non-significant results. Referring to the MAPE from Table 2, and selecting the lowest MAPE, we choose the Logistics regression in all eight cases.

\subsection{Discussion of results}

From Table 2 in four of the cases the R-squared test returned an unacceptable value, indicating that the curve fitted to the data is not a good fit. These cases include the Linear regression for wireless modules, Bass curve for electric motors, Bass curve for wireless modules, and Bass curve for routers.

The Linear regression and the Logistics regression forecasts are discussed next. 


\subsubsection{Linear regression forecasts}

Linear regression forecasts seem to follow the data closely for electric switchgear, electric motors, SCADA, PLCs, cell phones, routers, and antennas. For wireless modules we do not have a good fit (R-squared $=0.47$ ). This can be seen in Table 2 . Using the Linear regression is not practical, as in future period's growth is estimated to continue at a constant rate in all cases (except for 'short' time horizons where Linear regression may be considered).

This is a shortcoming of the Linear regression model. It is not possible to sustain Linear growth of new products indefinitely. This is indicated by the product-life cycle model, where products will eventually reach a point of maturity and decline as they are replaced by other disruptive products and technologies. Market conditions will definitely affect the life of a product, and so constant Linear growth cannot be achieved - which makes the Linear regression forecast an inappropriate choice for long term planning. Therefore one may opt for Linear regression for 'short' time horizons. More research is required in this area to determine the boundaries between 'short' and 'long' time horizons.

\begin{tabular}{|l|r|r|r|l|}
\hline \multicolumn{1}{c|}{$\begin{array}{c}\text { Product } \\
\text { description }\end{array}$} & $\begin{array}{c}\text { Linear } \\
\text { regression: } \\
\text { MAPE }\end{array}$ & $\begin{array}{c}\text { Logistics } \\
\text { regression: } \\
\text { MAPE }\end{array}$ & \multicolumn{1}{c|}{$\begin{array}{c}\text { Bass: } \\
\text { MAPE }\end{array}$} & $\begin{array}{c}\text { Lowest } \\
\text { MAPE }\end{array}$ \\
\hline Electronic Switchgear & 47.2 & 39.02 & 48.0 & Logisticsregression \\
R-Squared & 1.00 & 0.95 & 0.83 & \\
\hline Electric motors & 28.39 & 24.70 & 29.1 & Logisticsregression \\
R-Squared & 1.00 & 1.00 & 0.55 & \\
\hline SCADA & 26.6 & 22.70 & 27.3 & Logisticsregression \\
R-Squared & 1.00 & 0.98 & 0.86 & \\
\hline PLCs & 51.7 & 50.73 & 58.9 & Logisticsregression \\
R-squared & 1.00 & 0.75 & 0.98 & \\
\hline Cell phones & 66.0 & 18.7 & 22.0 & Logisticsregression \\
R-squared & 1.00 & 0.86 & 0.79 & \\
\hline Wireless modules & 168.96 & 118.34 & 179.19 & Logisticsregression \\
R-Squared & 0.47 & 0.95 & 0.50 & \\
\hline Routers & 53.43 & 47.17 & 51.95 & Logisticsregression \\
R-Squared & 1.00 & 1.00 & 0.16 & \\
\hline Antennas & 19.57 & 14.20 & 14.33 & Logisticsregression \\
R-Squared & 1.00 & 0.92 & 0.81 & \\
\hline
\end{tabular}

Table 2: Mean absolute percentage error for Linear regression, Logistics regression, and Bass curves

\subsubsection{Logistics and Bass forecasts}

From Table 2 it can be seen that in all cases the Logistics regression is a good fit for the data (R-squared $0.86<=X<=1$ ) with PLCs being the only exception (R-squared of 0.75 ). For the Bass curves in five of the cases we have a good fit (R-squared $0.79<=X<=0.98$ ); in three of the cases we have an unacceptable fit (R-squared $0.16<=x<=0.55$ ). Based on the discussion in section 6.2, it is proposed that the Logistics regression be selected as a forecasting tool. It may be argued that the Logistics regression should be used in conjunction with intuitive techniques like expert panel analysis, Delphi techniques, scenario planning, and relevance trees to achieve more realistic forecasts.

These intuitive techniques, together with mathematical forecasting techniques, may be used to reduce the MAPE further. The use of intuitive techniques may assist the forecaster in using collaborative techniques, which are believed to influence product life-circle curves ([3]). Through collaborative techniques, different paths of progress may be forecast. Forecasting different paths of progress may assist in obtaining more realistic forecasts. 
Having studied Linear regression, Logistics regression, and Bass curves, the remaining sections focus on the expert panel analysis, limitations of the research, further research areas, and conclusions.

\begin{tabular}{|c|c|c|c|c|c|c|c|c|c|c|}
\hline \multirow[b]{2}{*}{ 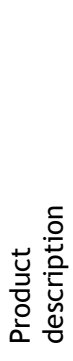 } & \multicolumn{10}{|c|}{ Source of variability } \\
\hline & 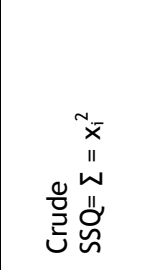 & 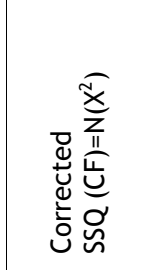 & 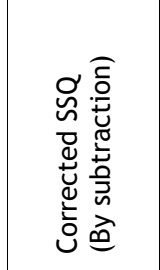 & 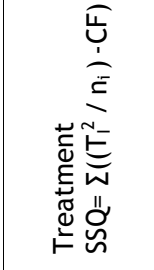 & 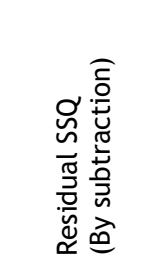 & 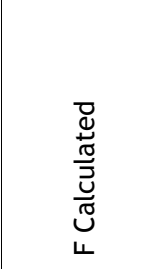 & 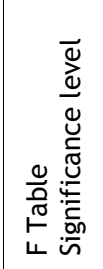 & 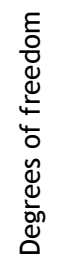 & 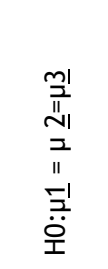 & $\begin{array}{l}n \\
z \\
\vdots \\
\sim\end{array}$ \\
\hline 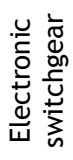 & $1.244 \mathrm{E}+12$ & $1.114 \mathrm{E}+12$ & $1.3034 \mathrm{E}+11$ & $8.76 \mathrm{E}+08$ & $1.294 \mathrm{E}+11$ & 0.22336422 & $\begin{array}{l}8.54 \\
0.001\end{array}$ & 66 & $\begin{array}{l}\text { Cannot } \\
\text { reject }\end{array}$ & N.S \\
\hline 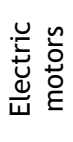 & $3.167 \mathrm{E}+14$ & $3.049 E+14$ & $1.183 \mathrm{E}+13$ & $7.325 \mathrm{E}+11$ & $1.110 \mathrm{E}+13$ & 2.17719063 & $\begin{array}{l}8.54 \\
0.001\end{array}$ & 66 & $\begin{array}{l}\text { Cannot } \\
\text { reject }\end{array}$ & N.S \\
\hline 㐫 & $1.841 \mathrm{E}+13$ & $1.701 \mathrm{E}+13$ & $1.403 \mathrm{E}+12$ & $3.44 \mathrm{E}+09$ & $1.399 E+12$ & 0.07735509 & $\begin{array}{l}8.54 \\
0.001\end{array}$ & 63 & $\begin{array}{l}\text { Cannot } \\
\text { reject }\end{array}$ & N.S \\
\hline $\begin{array}{l}\tilde{y} \\
a \\
\tilde{a}\end{array}$ & $8.572 E+12$ & $4.969 \mathrm{E}+12$ & $3.603 E+12$ & $6.0007 E+12$ & $-2.3966 \mathrm{E}+12$ & -78.8671014 & $\begin{array}{l}8.158 \\
0.001\end{array}$ & 63 & $\begin{array}{l}\text { Cannot } \\
\text { reject }\end{array}$ & NS \\
\hline$=\frac{\mathscr{d}}{\stackrel{\bar{d}}{0}}$ & $7.12 \mathrm{E}+08$ & $3.11 \mathrm{E}+08$ & $4.02 \mathrm{E}+08$ & $1.25 \mathrm{E}+07$ & $3.89 \mathrm{E}+08$ & 0.67273144 & $\begin{array}{l}9.075 \\
0.001\end{array}$ & 42 & $\begin{array}{l}\text { Cannot } \\
\text { reject }\end{array}$ & N.S \\
\hline 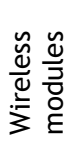 & $9.375 E+14$ & $8.469 E+14$ & $9.066 \mathrm{E}+13$ & $6.130 \mathrm{E}+12$ & $8.455 E+13$ & 5.32998333 & $\begin{array}{l}6.91 \\
0.001\end{array}$ & 147 & $\begin{array}{l}\text { Cannot } \\
\text { reject }\end{array}$ & N.S \\
\hline 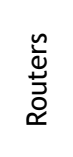 & $3.663 \mathrm{E}+16$ & $3.623 E+16$ & $4.002 E+14$ & $1.09 \mathrm{E}+14$ & $2.910 E+14$ & 14.6295385 & $\begin{array}{l}10.101 \\
0.001\end{array}$ & 78 & $\begin{array}{l}\text { Cannot } \\
\text { reject }\end{array}$ & N.S \\
\hline 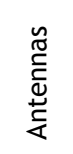 & $2.871 \mathrm{E}+14$ & $2.300 E+14$ & $5.7074 \mathrm{E}+13$ & $1.302 \mathrm{E}+11$ & $5.691 \mathrm{E}+13$ & 0.08578159 & $\begin{array}{l}9.71 \\
0.001\end{array}$ & 75 & $\begin{array}{c}\text { Cannot } \\
\text { reject }\end{array}$ & N.S \\
\hline
\end{tabular}




\begin{tabular}{|c|c|c|c|}
\hline \multirow[b]{2}{*}{$\begin{array}{l}\text { Product } \\
\text { description }\end{array}$} & \multicolumn{2}{|c|}{ Logistics regression } & \multirow[b]{2}{*}{ Comments } \\
\hline & $\begin{array}{l}\text { Expert } \\
\text { panel view } \\
\text { on long } \\
\text { range } \\
\text { forecasts }\end{array}$ & $\begin{array}{l}\text { Expert panel } \\
\text { view on } \\
\text { short range } \\
\text { forecasts }\end{array}$ & \\
\hline $\begin{array}{l}\text { Electronic } \\
\text { switchgear }\end{array}$ & No & Yes & $\begin{array}{l}\text { Expert panel preferred the Logistics regression } \\
\text { with short range forecasting due to the short lead- } \\
\text { times from customer requirements and distributor } \\
\text { channels. }\end{array}$ \\
\hline $\begin{array}{l}\text { Electric } \\
\text { motors }\end{array}$ & Yes & No & $\begin{array}{l}\text { Expert panel preferred the Logistics regression } \\
\text { long range forecasts, as electric motors required } \\
\text { longer manufacturing lead-times, and often these } \\
\text { products were planned well in advance from a } \\
\text { customer perspective. }\end{array}$ \\
\hline SCADA & Yes & No & $\begin{array}{l}\text { Expert panels preferred long range forecasts, as } \\
\text { often these products were used in a systems } \\
\text { engineering environment, and were also often } \\
\text { used in capital intensive environments; so long } \\
\text { rage forecasting was appropriate. }\end{array}$ \\
\hline PLCs & Yes & No & $\begin{array}{l}\text { Expert panels preferred long range forecasts, as } \\
\text { often these products were used in a systems } \\
\text { engineering environment, and were also often } \\
\text { used in capital intensive environments; so long } \\
\text { rage forecasting was appropriate. }\end{array}$ \\
\hline Cell phones & No & Yes & $\begin{array}{l}\text { Expert panel preferred short range forecasting, } \\
\text { due to the rapidly changing technological } \\
\text { environment that these products compete in. }\end{array}$ \\
\hline $\begin{array}{l}\text { Wireless } \\
\text { modules }\end{array}$ & No & Yes & $\begin{array}{l}\text { Expert panel preferred short range forecasting, } \\
\text { due to the rapidly changing technological } \\
\text { environment that these products compete in. }\end{array}$ \\
\hline Routers & No & Yes & $\begin{array}{l}\text { Expert panel preferred short range forecasting, } \\
\text { due to the rapidly changing technological } \\
\text { environment that these products compete in. }\end{array}$ \\
\hline Antennas & Yes & No & $\begin{array}{l}\text { Expert panel preferred long range forecasts, as } \\
\text { these items are not prone to rapid technological } \\
\text { change, and there is a high demand for the } \\
\text { product. }\end{array}$ \\
\hline
\end{tabular}

Table 4: Summary of expert panel viewpoints

\section{EXPERT PANEL ANALYSIS}

Having completed the mathematical analysis, two expert panels were set up to obtain a better understanding of forecasting: one for the electronics and electrical engineering industry, and the other for the ICT industry. The expert panels were briefed on the results of the mathematical forecasts for short range forecasts ( 3 periods), and were asked to comment on the views on short and long term forecasts. The results are summarised in Table 4. From Table 4 we see that in the majority of the cases the electronics and electrical engineering industry preferred long range forecasts, whereas the ICT panel preferred short range forecasts. The expert panels from both industries indicated that they used both short and long range forecasts. Long range forecasts were preferred for annual budgeting and forecasting, whereas short range forecasts were preferred for shorter term planning for both industry sectors. Table 3 shows the ANOVA for short range forecasts. We see no differences for short range forecast between the curves. Therefore we may conclude for short range forecasting that any of the three curves would be an appropriate choice. Making a selection on the lowest MAPE, we choose the Logistics regression. Similar trends are shown for long range Forecasts in Table 5. 


\begin{tabular}{|c|c|c|c|c|c|c|c|c|c|c|}
\hline \multirow[b]{2}{*}{ 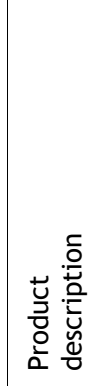 } & \multicolumn{10}{|c|}{ Source of variability } \\
\hline & 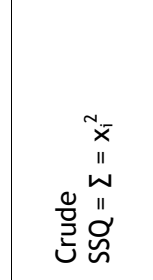 & 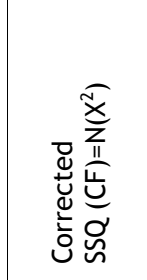 & 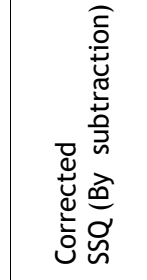 & 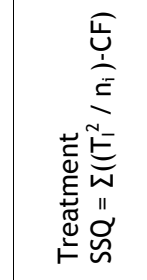 & 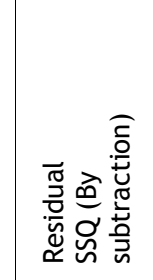 & 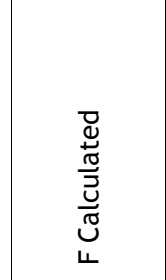 & 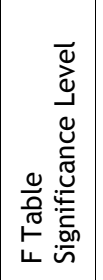 & 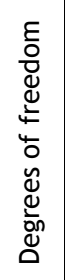 & 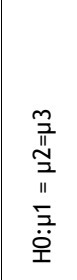 & $\begin{array}{l}u \\
z \\
\vdots \\
\vdots\end{array}$ \\
\hline 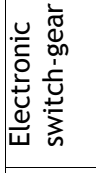 & $2.360 \mathrm{E}+12$ & $2.026 \mathrm{E}+12$ & $3.346 \mathrm{E}+11$ & $6.12 E+09$ & $3.284 \mathrm{E}+11$ & 0.80995595 & $\begin{array}{l}8.946 \\
0.001\end{array}$ & 87 & 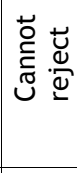 & $\tilde{z}$ \\
\hline 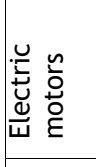 & $1.513 E+16$ & $5.249 E+15$ & $9.889 \mathrm{E}+15$ & $6.328 \mathrm{E}+15$ & $3.560 \mathrm{E}+15$ & 77.3262816 & $\begin{array}{r}11.266 \\
0.001 \\
\end{array}$ & 87 & 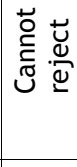 & $\tilde{z}$ \\
\hline 悥 & $3.112 \mathrm{E}+13$ & $2.799 E+13$ & $3.134 E+12$ & $3.00 \mathrm{E}+10$ & $3.104 E+12$ & 0.39138076 & $\begin{array}{r}9.88 \\
0.001\end{array}$ & 81 & 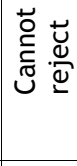 & $\tilde{z}$ \\
\hline $\begin{array}{l}\tilde{U} \\
\underline{\Delta} \\
\tilde{n}\end{array}$ & $5.225 \mathrm{E}+13$ & $1.771 \mathrm{E}+13$ & $3.454 \mathrm{E}+13$ & $5.612 \mathrm{E}+12$ & $2.893 \mathrm{E}+13$ & 8.4382727 & $\begin{array}{l}6.94 \\
0.01\end{array}$ & 87 & 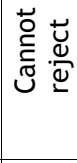 & $\tilde{z}$ \\
\hline$=\frac{\mathscr{U}}{\bar{\Xi}}$ & $2.879 E+11$ & $1.29 E+10$ & $2.750 E+11$ & $1.63 \mathrm{E}+10$ & $2.586 \mathrm{E}+11$ & 1.60873255 & $\begin{array}{r}12.78 \\
0.01\end{array}$ & 51 & 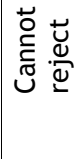 & $\stackrel{\sim}{z}$ \\
\hline 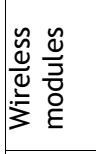 & $8.137 \mathrm{E}+15$ & $3.306 \mathrm{E}+15$ & $4.831 \mathrm{E}+15$ & $4.719 E+14$ & $4.359 \mathrm{E}+15$ & 11.2047797 & $\begin{array}{r}6.91 \\
0.001\end{array}$ & 207 & 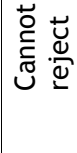 & $\tilde{z}$ \\
\hline 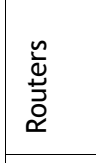 & $3.663 \mathrm{E}+16$ & $3.623 E+16$ & $4.002 E+14$ & $1.09 \mathrm{E}+14$ & $2.910 E+14$ & 14.6295385 & $\begin{array}{r}10.101 \\
0.05 \\
\end{array}$ & 78 & 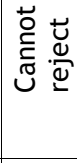 & $\tilde{z}$ \\
\hline 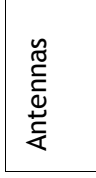 & $9.375 E+14$ & $6.222 \mathrm{E}+14$ & $3.153 E+14$ & $1.195 \mathrm{E}+13$ & $3.034 \mathrm{E}+14$ & 1.94986405 & $\begin{array}{l}12.82 \\
0.001\end{array}$ & 99 & 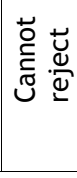 & $\tilde{z}$ \\
\hline
\end{tabular}

Table 5: ANOVA for each product long range forecasts 
From the expert panel discussions it is apparent that in some instances long range forecasts were preferred, and in some cases short range forecasts were preferred. These choices were dependent upon the market conditions in which the products were positioned. Figures 1 and 2 show the Logistics regression forecasts for the electronics and electrical engineering industries and ICT industries respectively.

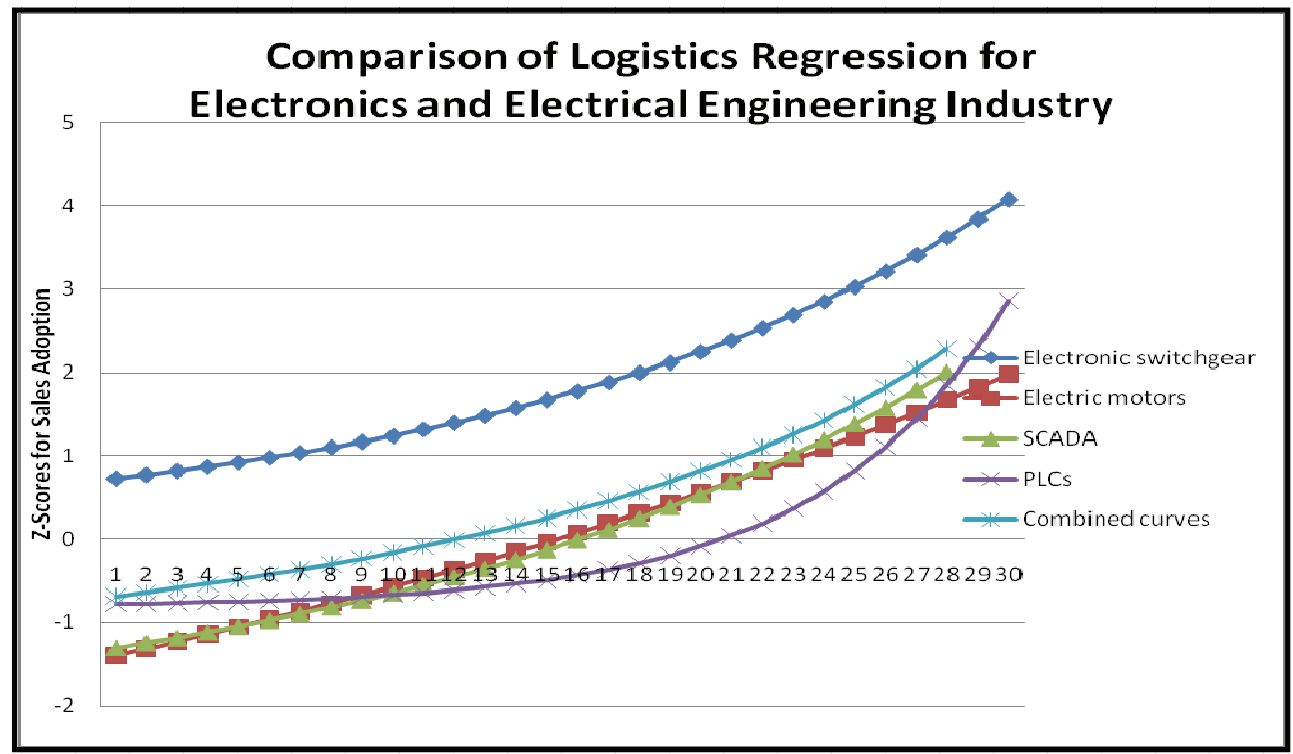

Figure 1: Logistics regression for electronics and electrical engineering industries

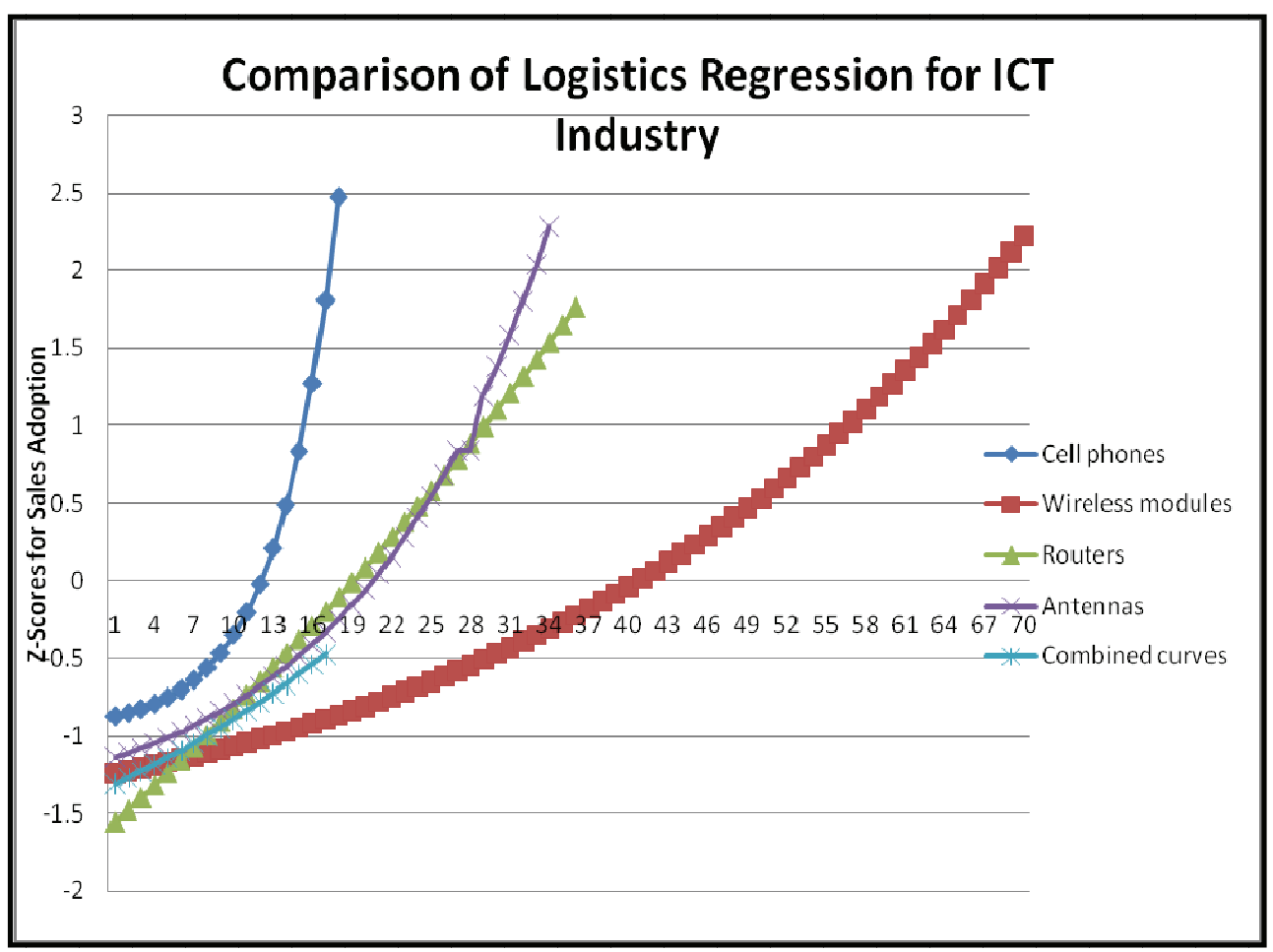

Figure 2: Logistics regression for information and communications technology Industry 
For both sectors we see no significant differences between the curves ( $F$ (calculated) < $\mathrm{F}($ table)) for the products selected. In addition, we normalise the curves, and - comparing the two industries - we see that the electronics and electrical engineering industry has more rapid growth than the ICT industry.

It is interesting to notice that the expert panels for the electronics and electrical engineering industry and ICT industries preferred long and short range forecasts respectively.

Figure 3 shows the comparison between the two industries. Comparing the two industries statistically, we see no significant differences between the curves, $F$ (calculated) $<F($ table). Graphically the electronic and electrical engineering industry has a steeper adoption curve than the ICT industry.

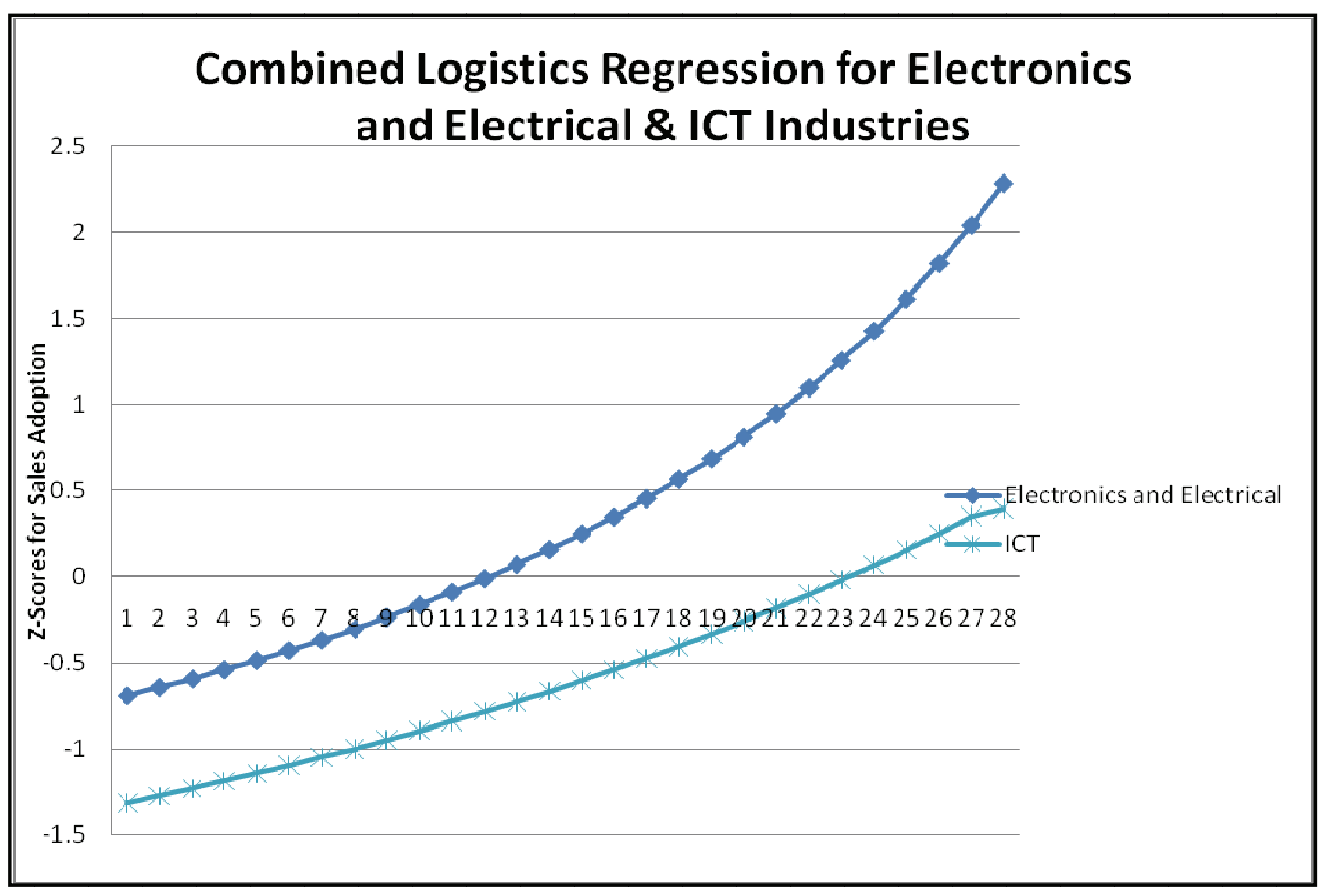

Figure 3: Logistics regression for electronics \& electrical and ICT industries

\section{LIMITATIONS OF THE RESEARCH}

Data collection was difficult, as firms were not keen to divulge their sales figures for new products. In respect of the electronics and electrical engineering industries, four products were selected from a single equipment manufacturer. Further analysis of other products from other manufacturers would certainly give more robustness to the validity of the forecasting. In the ICT industry, four types of products were studied; here too, more analysis of different products from other manufacturers would add more robustness to the analysis.

\section{CONCLUSIONS AND FURTHER RESEARCH}

Eight data sets were collected, and their scales were appropriately adjusted. For these data sets the Linear regression, Logistics regression, and Bass curves were plotted. Appropriate forecasting horizons were selected and the R-squared goodness of fit test was carried out to determine the accuracy of the data. Logistics regression was found to be an appropriate choice as a forecasting tool (lowest MAPE) for new product development; 
however, the effectiveness of Logistics regression could be improved through intuitive techniques. The results obtained here confirm the discussion in the literature survey (Section 3.1) where it is shown that mathematical forecasting findings vary. Therefore mathematical forecasting was used in conjunction with intuitive techniques to improve the accuracy of forecasts. The use of intuitive techniques may be used to generate different paths regarding short and long range forecasts. In our cases, an expert panel was used to assist the forecaster in choosing the appropriate path of progress that best fits his/her needs.

Intuitive techniques could assist in identifying factors that affect Logistics regression; these factors could include time, market size and demographics, technological limits of the product or technology, supporting infrastructure, customer satisfaction and service levels, etc.

For example, [7] argue that cell phones were a great invention, but their commercial success depended on the development of switching software and equipment, service providers, and forecasts of microwave towers. This can also be said for the digital television technology that will be introduced into the South African market in the next few years.

[9] suggest the use of chaos theory to identify certain parameter values, as diffusion models generate persistent chaotic behaviour within predictable boundaries:

- $\quad$ Comparing the Logistics regression to other forecasting models.

- Comparing of Logistics regression in other industries.

- Comparing Logistics regression for phasing out existing products, technologies, or services, and phasing in newer products, technologies, or services.

- Comparison of Logistics regression for different types of technological products in the technological hierarchy. It is suggested the technological hierarchy proposed by [12] - i.e. open systems, closed systems, simple assembled products, and nonassembled products - be used. Differences within and between categories may be explored. Further data collection and comparison of Logistics regression with competitors' products is needed. This could be difficult as firms are not willing to share this kind of data. However, obtaining more readily available information - for example, on service providers in the ICT industry - should be possible. Such information should also be available from the automotive industry

\section{ACKNOWLEDGEMENTS}

The following are acknowledged:

[1] The contributions made by Mr D. Doucakis at the University of Witwatersrand on initial work on technological forecasting in preparation for project reports.

[2] The contributions made by Daniel Messen on work done on VBA programming for the models developed.

[3] All other participants in the research.

\section{REFERENCES}

[1] Abernathy, W.J. \& Utterback, J.M. 1988. Patterns of industrial innovation, In: Tushman, M.L. and Moore, W.L., Readings in the management of innovation, $2^{\text {nd }}$ edition, Harper Business, 25-36.

[2] Bower, J.L. \& Christensen, C.M. 1995. Disruptive technologies: Catching the wave, Harvard Business Review, January-February, 43-53.

[3] Cormican, K. \& O'Sullivan, D. 2004. Auditing best practice for effective product innovation management, Technovation, 24, 819-829.

[4] Day, G.S. \& Schoemaker, P.J.H. 2000, Managing emerging technologies, John Wiley and Sons, Inc. 
[5] Foster, R.N. 1988. Timing technological transitions, In: Tushman, M.L., Moore, W.L., Readings in the management of innovation, $2^{\text {nd }}$ edition, Harper Business, 215228.

[6] Gomes, J.F.S., De Weerd-Nederhof, P.C., Pearson, A.W. \& Cunha, M.P. 2003. Is more always better? An exploration of the differential effects of functional integration on performance in new product development, Technovation, 23, 185191.

[7] Leifer, R., Mcdermott, C.M., O'Connor, G.C., Peters, L.S., Rice, M. \& Veryzer, R.W. 2000, Radical innovation: How mature companies can outsmart upstarts, Harvard Business School Press.

[8] Hair, J.F. Jr., Anderson, R.E., Tatham, R.L. \& Black, W.C. 1998. Multivariate data analysis, Prentice Hall, $5^{\text {th }}$ edition.

[9] Mahajan, V., Muller, E. \& Bass, F.M. 1990. New product diffusion models in marketing: A review and directions for research, Journal of Marketing, Vol. 54, 1-26.

[10] Martino, J.P. 1993. Technological forecasting for decision making, McGraw-Hill, $3^{\text {rd }}$ edition.

[11] Oliver, R.M. \& Yang, H.J. 1988. Saturation models: A brief survey and critique, Journal of Forecasting, 7, 215-223.

[12] Siriram, R. \& Snaddon, D.R. 2004. Linking technology management, transaction processes and governance structures, Technovation, 24, 779-791.

[13] Siriram, R. \& Snaddon, D.R. 2005. Verifying links in technology management, transaction processes and governance structures, Technovation, 25, 321-337.

[14] Stock, G.N., Greis, N.P. \& Fischer, W.A. 2002. Firm size and dynamic technological innovation, Technovation, 22, 537-549.

[15] Tidd, J., Bessant, J. \& Pavitt, K. 2001. Managing innovation: Integrating technological, market and organizational change, John Wiley and Sons Ltd., $2^{\text {nd }}$ edition.

[16] Tushman, L. \& Anderson, P. 1986. Technological discontinuities and organizational environments, Administrative Science Quarterly, 31, 439-465.

[17] Tushman, M.L. \& Rosenkopf, L., 1992. Organizational determinants of technological change: Toward a sociology of technological evolution, Research In Organizational Behaviour, Vol. 14, 311-345.

[18] Twiss, B.C. 1980. Technological forecasting for decision making, In: Burgleman, R.A., Maidique, M.A. \& Wheelwright, S.C., Strategic management of technology and innovation, $2^{\text {nd }}$ edition, McGraw Hill, 1996.

[19] Takayama, M., Watanabe, C. \& Griffy Brown, C. 2002. Remaining innovative without sacrificing stability: An analysis of strategies in the Japanese pharmaceutical industry that enable firms to overcome inertia resulting from successful market penetration of new product development, Technovation, 22, 747-759.

[20] Young, P. 1993. Technological growth curves, a competition of forecasting models, Technological Forecasting sand Social Change, 44, 375-389.

[21] Young, P. \& Ord, J.K. 1989. Model selection and estimation for technological growth curves, International Journal of Forecasting, 5, 501-513.

[22] Winklhofer, H.M. \& Diamantopoulos, A. 2002. Managerial evaluation of sales forecasting effectiveness: A MIMIC modelling approach, International Journal of Research in Marketing, 19, 151-166. 
http://sajie.journals.ac.za 